Int. J. Electrochem. Sci., 14 (2019) $2693-2704$

International Journal of

ELECTROCHEMICAL

SCIENCE

www.electrochemsci.org

\title{
Synergistic Effect between Chloride and Sulfate Reducing Bacteria in Corrosion Inhibition of X100 Pipeline Steel in Marine Environment
}

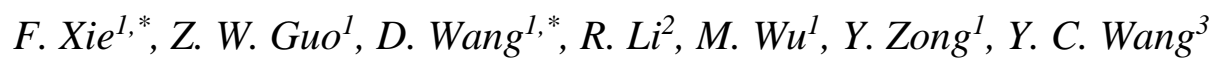 \\ ${ }^{1}$ Storage and Transportation, College of Petroleum Engineering, Liaoning Shihua University, Fushun, \\ Liaoning, 113001, China. \\ ${ }^{2}$ PetroChina Liaoning Fushun Marketing Company, Fushun, Liaoning, 113006, China. \\ ${ }^{3}$ PetroChina Northeast Marketing Company, Shenyang, Liaoning, 110000, China \\ *E-mail: xiefei0413@163.com,wd841015@163.com
}

doi: $10.20964 / 2019.03 .54$

Received: 17 October 2018 / Accepted: 26 December 2018 / Published: 7 February 2019

\begin{abstract}
Large amounts of chloride ions and sulfate reducing bacteria (SRB) are present in marine environments owing to which the corrosion of subsea pipeline steel is inevitable. In this study, the influence of chloride content on the corrosion behavior of X100 pipeline steel in seawater containing SRB was investigated, using electrochemical impedance spectroscopy and potentiodynamic polarization. The adhesion and film layer state of SRB at different chloride contents were observed by scanning electron microscopy. The results show that an appropriate increase in chloride concentration is beneficial for SRB growth, but when the chloride concentration is too high, the growth of SRB is inhibited. In this study, the optimum salinity for SRB growth is found to be $35 \mathrm{~g} \mathrm{~L}^{-1}$. Under the combined effect of SRB and chloride ions, with an increase in the chloride concentration, the corrosion rate of X100 pipeline steel decrease after an initial increasing trend. When the chloride concentration is $35 \mathrm{~g} \mathrm{~L}^{-1}$, the metal surface film is the densest and most protective, and the corrosion rate of the specimen is minimal. This is because of the synergism between the destructive effect of chloride ions on the surface film of the electrode and the influence of chloride ions on the SRB growth process.
\end{abstract}

Keywords: X100 pipeline steel; sulfate reducing bacteria (SRB); chloride; corrosion behavior

\section{$\underline{\text { FULL TEXT }}$}

(C) 2019 The Authors. Published by ESG (www.electrochemsci.org). This article is an open access article distributed under the terms and conditions of the Creative Commons Attribution license (http://creativecommons.org/licenses/by/4.0/). 